\title{
Mechanical Ventilation Alters Airway Nucleotides and Purinoceptors in Lung and Extrapulmonary Organs
}

\author{
Christelle D. Douillet, William P. Robinson III, Ben L. Zarzaur, Eduardo R. Lazarowski, Richard C. Boucher, \\ and Preston B. Rich
}

Departments of Surgery and Medicine, University of North Carolina at Chapel Hill, Chapel Hill, North Carolina

\begin{abstract}
Extracellular nucleotides are stress-responsive ligands that mediate a variety of cellular processes via purinoceptors. We hypothesized that mechanical ventilation (MV) would alter the extracellular adenyl-nucleotide profile and purinoceptor expression in lung and extrapulmonary tissues. Twenty-eight rats were randomized to: (i) unventilated control animals; (ii) tidal volume $\left(\mathrm{V}_{\mathrm{T}} ; 6 \mathrm{ml} / \mathrm{kg}\right)$; (iii) $\mathrm{VT}_{\mathrm{T}}(6 \mathrm{ml} / \mathrm{kg})$ and positive end-expiratory pressure (PEEP; $5 \mathrm{~cm} \mathrm{H} \mathrm{H}_{2}$ ); (iv) $\mathrm{V}_{\mathrm{T}}(12 \mathrm{ml} / \mathrm{kg})$; or $(v) \mathrm{V}_{\mathrm{T}}(12 \mathrm{ml} / \mathrm{kg})$ and PEEP $\left(5 \mathrm{~cm} \mathrm{H} \mathrm{H}_{2} 0\right)$. Bronchoalveolar lavage (BAL) was analyzed for adenyl-nucleotides. Pulmonary, hepatic, and renal tissues were assessed for $P_{2} Y_{4}, P_{2} Y_{6}$, $P_{2} X_{7}, A_{3}$, and $A_{2 b}$ receptor expression by real-time reverse transcriptase-polymerase chain reaction and Fas/Fas ligand mRNA was quantified in the lung. MV produced volume-dependent changes in BAL nucleotides; AMP and adenosine increased, whereas ATP and ADP proportions decreased. Large-volume $M V$ increased $A_{2 b}$ mRNA and decreased $P_{2} X_{7}$ in the lung; mRNA changes in lung Fas ligand paralleled $P_{2} X_{7}$. PEEP normalized $B A L$ nucleotide profiles and $A_{2 b}$ expression. Injurious $M V$ reduced hepatic and renal $P_{2} X_{7}$ mRNA; PEEP normalized these levels in both tissues. Large-volume $M V$ also decreased renal $A_{2 b}$ mRNA. MV alters the BAL adenyl-nucleotide profile and purinoceptor patterns in lung, liver, and kidney. PEEP normalizes the BAL nucleotide profile and receptor patterns in lung and extrapulmonary tissues.
\end{abstract}

Keywords: mechanical ventilation; nucleotide; purinoceptor; ventilatorinduced lung injury

Clinical studies support basic scientific observations that mechanical ventilation (MV), particularly with large tidal volumes (VTS), can be injurious (1). Although it is known that large-volume ventilation can produce histologic lung injury, pulmonary edema, capillary stress failure, local and systemic inflammation, and, ultimately, increased mortality, the mechanisms responsible for these events are unknown (1). Although transpulmonary shearstress and alveolar overdistension can result in direct physical disruption of anatomic structures at extremes, it is clear that distension of a lesser magnitude can produce lung injury and induce ventilation-associated pathologic responses in extrapulmonary tissues (2). Consequently, it is important to identify a system of mechanotransduction capable of translating airway stress to intracellular signaling pathways at the molecular level.

Extracellular nucleotides are stress-responsive molecules that mediate a host of physiologic responses via ubiquitous mem-

(Received in original form June 1, 2004 and in revised form August 30, 2004)

Presented, in part, at the 2004 International Conference of the American Thoracic Society in Orlando, Florida.

Supported by grant 1 K08 HL72836-01 from the National Heart, Lung, and Blood Institute of the National Institutes of Health.

Correspondence and requests for reprints should be addressed to Preston B. Rich M.D., Department of Surgery, Section of Critical Care, University of North Carolina at Chapel Hill, School of Medicine, Medical School Wing D, Room 186, CB\#7228, Chapel Hill, NC 27599-7228. E-mail: prich@med.unc.edu

Am J Respir Cell Mol Biol Vol 32. pp 52-58, 2005

Originally Published in Press as DOI: 10.1165/rcmb.2004-01770C on September 23, 2004

Internet address: www.atsjournals.org brane-bound purinoceptors $(3,4)$. It is known that shear-stress at the cellular level is a potent physical stimulus for the regulated release of nucleotides in a host of cell types, including pulmonary epithelium and vascular endothelium $(5,6)$. A variety of extracellular and cell surface-associated enzymes tightly regulate the extracellular nucleotide profile and provide a complex environment for differential stimulation of the purinergic receptor superfamilies $(3,7)$.

Through changes in transmembrane ionic conductance or G-protein-linked intracellular signaling pathways, purinergic stimulation produces diverse responses in cell culture-based in vitro assays $(3,4,8,9)$. In smooth muscle cells, inflammatory cells, and lung epithelia, extracellular nucleotides regulate vascular tone and alter transmembrane ionic conductance and fluid dynamics $(3,4)$. Furthermore, purinergic stimulation can modulate cytokine release, induce apoptosis, and coordinate a variety of proximal nuclear transcriptional signals $(10,11)$. Many of these processes have been mechanistically implicated in the pathogenesis of ventilator-associated lung injury.

We have previously demonstrated with luminometric assays that MV generates an increase in luminal ATP levels and that pharmacologic receptor stimulation in vivo can induce changes in the lung commonly observed with ventilator-associated lung injury $(12,13)$. We hypothesized that MV would alter the total adenyl nucleotide profile within the airspaces and produce changes in purinergic expression patterns, both within the lung and select extrapulmonary tissues, thereby modifying the purinergic receptor-ligand milieu.

\section{MATERIALS AND METHODS}

Animals

All experimental procedures and protocols were approved by the Institutional Animal Care and Use Committee at the University of North Carolina at Chapel Hill. A total of 28 male Sprague-Dawley rats (body weight: $481 \pm 6.8 \mathrm{~g}$ ) were obtained from Harlan (Indianapolis, IN). Animals were block-randomized into five groups: $(i)$ control (Ctrl, no $\mathrm{MV}, n=6$ ) or MV with: (ii) small VT with positive end-expiratory pressure (PEEP) (V6P, VT $\left.=6 \mathrm{ml} / \mathrm{kg}, \mathrm{PEEP}=5 \mathrm{~cm} \mathrm{H} \mathrm{H}_{2} \mathrm{O}, n=5\right)$; (iii) small VT with zero end-expiratory pressure (ZEEP) $(\mathrm{V} 6 \mathrm{Z}, \mathrm{VT}=6 \mathrm{ml} / \mathrm{kg}$, PEEP $=0 \mathrm{~cm} \mathrm{H}_{2} \mathrm{O}, \mathrm{n}=5$ ); (iv) large VT with ZEEP (V12Z, VT $=12$ $\left.\mathrm{ml} / \mathrm{kg}, \mathrm{PEEP}=0 \mathrm{~cm} \mathrm{H}_{2} \mathrm{O}, n=6\right)$; and $(v)$ large VT with PEEP (V12P, $\mathrm{VT}=12 \mathrm{ml} / \mathrm{kg}, \mathrm{PEEP}=5 \mathrm{~cm} \mathrm{H}_{2} \mathrm{O}, n=6$ ).

Animals were anesthetized with pentobarbital (USP, $50 \mathrm{mg} / \mathrm{kg}$ intraperitoneal; Abbott Laboratories, North Chicago, IL) and the cervical trachea was cannulated via midline cervical incision. Control animals breathed spontaneously through the cannula. After confirming a surgical plane of anesthesia, MV animals were chemically paralyzed (pancuronium bromide $0.4 \mathrm{mg} / \mathrm{kg}$, intravenous; Abbott Laboratories) and connected to a small-animal ventilator (Inspira ASV; Harvard Instruments, Holliston, MA), which defined time 0. MV animals were ventilated according to protocol randomization, with room air, at a respiratory rate of 60 breaths per minute (bpm) and an inspiratory:expiratory ratio of 1:1. After $2 \mathrm{~h}$, blood was sampled from the jugular vein. Bronchoalveolar lavage (BAL) was performed by slowly instilling $2 \mathrm{ml}$ of sterile solution $(0.9 \% \mathrm{NaCl}$ containing $10.5 \mathrm{mM}$ buffered sodium citrate, $\mathrm{pH}=$ 7.3 ) intratracheally, followed by $2 \mathrm{ml}$ of air. Lung fluid was drained by gravity and gentle abdominal massage, and specimens were collected 
TABLE 1. OLIGONUCLEOTIDE PRIMERS USED TO DETECT RECEPTOR SUBTYPES BY REAL-TIME REVERSE TRANSCRIPTASE-POLYMERASE CHAIN REACTION

\begin{tabular}{lll}
\hline Gene & \multicolumn{1}{c}{ Forward } & \multicolumn{1}{c}{ Reverse } \\
\hline $\mathrm{A}_{2 b}$ & TTTCACAGCTGCCTCTTCCT & GGTGGCACGGTCTTTACTGT \\
$\mathrm{A}_{3} \mathrm{P}_{4}$ & GTCTTCACCCATGCTTCCAT & GGGTGGAGCTGTTTGAGAG \\
$\mathrm{P}_{2} \mathrm{Y}_{4}$ & CTGGGCTGGACTAAGGAAGC & CATGTAGGTGGCTGTTGCAT \\
$\mathrm{P}_{2} \mathrm{Y}_{6}$ & GTGGAATTCAGGCTGAGGAC & GCCTGCTTTCCTATGCTTG \\
$\mathrm{P}_{2} \mathrm{X}_{7}$ & GCGTTTGACATCCTGGTTT & AAGAAGTCCTCTGGGGTCT \\
Fas & GGGCATGGTTTAGAAGTGGA & GGATTCCAGATTCAGGTCA \\
Fas ligand & AACCAAAAAGCCAAGGAGTGT & TCTTCTCCTCCATTAGCACCA \\
GAPDH & AGGTGACCGCATCTTCTTGT & CTTGCCGTGGGTAGAGTCAT
\end{tabular}

Definition of abbreviation: GAPDH, glyceraldehyde-3-phosphate dehydrogenase.

on ice. Animals then received a lethal intravenous injection of pentobarbital, and tissue samples from lungs, liver, and kidney were harvested and immediately preserved in RNAlater solution (Qiagen, Valencia, CA).

\section{Urea-Based Epithelial Lining Fluid Volume Determination}

BAL and serum urea concentrations were determined using a commercially available kit (Sigma, St. Louis, MO). The simultaneous determination of urea concentrations in paired serum and BAL samples $\left(\right.$ Urea $_{\text {serum }}$ and Urea $_{\mathrm{BAL}}$, respectively) permitted the calculation of the volume of epithelial lining fluid as described by the equation: epithelial lining fluid $=\left(\right.$ Urea $\left._{\mathrm{BAL}} / \mathrm{Urea}_{\text {erum }}\right) \times \mathrm{Vol}_{\mathrm{BAL}}$, where $\mathrm{Vol}_{\mathrm{BAL}}$ is the volume of BAL collected (14).

\section{Protein}

Total BAL protein content was measured spectrophotometrically by the commercially available bicinchoninic acid protein assay (Pierce, Rockford, IL).

\section{Nucleotide Analysis}

Immediately after iced collection, BAL samples were centrifuged at $4^{\circ} \mathrm{C}$, and supernatants boiled for $2 \mathrm{~min}$. Nucleotides were derivatized into fluorescent $1, \mathrm{~N}^{6}$-ethenopurines for quantification by high-pressure liquid chromatography (HPLC), according to the technique previously described by Lazarowski and colleagues $(15,16)$. Briefly, samples were incubated at $72^{\circ} \mathrm{C}$ with $1 \mathrm{M}$ chloroacetaldehyde, $25 \mathrm{mM} \mathrm{Na}_{2} \mathrm{HPO}_{4}$, then alkalinized with $\mathrm{NH}_{4} \mathrm{HCO}_{3}$ before analysis by HPLC (Waters, Milford, MA) using a PRP-X100 anion exchange column (Hamilton, Reno, NV). HPLC fluorescence was integrated and analyzed using Millennium software (Waters). Data from test samples were compared against known concentrations of ATP, ADP, AMP, and adenosine (ADO), which were derivatized and analyzed in parallel; these control samples were injected at the beginning and again at the end of each HPLC injection set to determine within-run precision $(<3 \%)$.

\section{Real-Time Reverse Transcriptase-Polymerase Chain Reaction}

Tissue RNA was extracted using Qiagen RNeasy kit. RNA quality was assessed spectrophotometrically and by denaturating agarose gel electrophoresis. cDNAs were prepared using random primers and moloney murine leukemia virus reverse transcriptase (SuperScriptII RNase
$\mathrm{H}^{-} \mathrm{RT}$; Invitrogen, Carlsbad, CA), as per manufacturer's instructions. For real-time polymerase chain reaction (PCR), primer sets, described in Table 1, were designed using the NCBI website, Primer3 (Whitehead Institute, Cambridge, MA) and Genosys (Sigma) software. Primers were synthesized by MWG Biotech Inc. (Charlotte, NC). Real-time PCR was performed on a LightCycler Instrument (Roche Diagnostics, Indianapolis, IN), using LightCycler FastStart DNA Master SYBR Green I (Roche), following the manufacturer's instructions. The crossing point $(\mathrm{CP})$ for each sample was determined by LightCycler LCDA version 3.5.28 Software (Roche). Each sample was amplified at least in duplicate, for which the CP SD was $<0.5$. For each run, a negative control was performed, in which the cDNA template was replaced by water. Melting curves facilitated discrimination between potential primer dimers and specific amplified products, and controlled for the homogeneity of a single amplified sequence. Serial dilutions of a control template permitted the establishment of a standard curve. The slope of the linear regression of the $\mathrm{CP}$ versus the log cDNA concentration was used to calculate amplification efficiency $(\mathrm{E})$, as $\mathrm{E}=10^{\text {(1/lope })}$. The relative quantification of gene mRNA levels was calculated as a ratio (R), in comparison to a reference gene, glyceraldehyde-3-phosphate dehydrogenase (GAPDH). The equation for R, as described by Pfaffl (17), was:

$$
\mathrm{R}=\mathrm{E}_{\text {target }}\left(\mathrm{CP}_{\text {target }} \text { control-CP } \mathrm{C}_{\text {target }} \text { sample }\right) / \mathrm{E}_{\mathrm{ref}}\left(\mathrm{CP}_{\text {ref }} \text { control-CP } \mathrm{Cef}_{\text {ref }} \text { sample }\right)
$$

where $E_{\text {target }}$ and $E_{\text {ref }}$ are, respectively, the efficiency of target gene and reference gene $(\mathrm{GAPDH}) ; \mathrm{CP}_{\text {target }}$ control is the average of crossing points of control animals cDNA for the target gene; $\mathrm{CP}_{\text {target }}$ sample is the crossing point of the sample for the target gene; $\mathrm{CP}_{\text {ref }}$ control is the average of crossing points of control animals cDNA for the reference gene; $\mathrm{CP}_{\text {ref }}$ sample is the crossing point of the sample for the reference gene.

\section{Statistical Analysis}

Data are presented as mean \pm SEM. Data were analyzed by ANOVA and Fisher's PLSD tests where appropriate. Significance was defined as $P<0.05$.

\section{RESULTS}

\section{Airway Pressures}

All animals survived the 2-h experimental period of MV. Airway pressures were monitored during $\mathrm{MV}$ and are reported in Table 2. The delivery of larger VTs significantly increased peak inspiratory pressure $(P<0.0001 \mathrm{~V} 12 \mathrm{Z}$ versus V6Z; $P<0.0001$ $\mathrm{V} 12 \mathrm{P}$ versus $\mathrm{V} 6 \mathrm{P}$ ), and mean airway pressure (MPaw; $P=0.001$ V12Z versus V6Z; $P=0.02 \mathrm{~V} 6 \mathrm{P}$ versus V12P). Due to the volume-controlled ventilatory mode, the addition of PEEP increased MPaw and peak inspiratory pressure (MPaw; $P<0.0001$ V6P versus V6Z; $P<0.0001 \mathrm{~V} 12 \mathrm{P}$ versus V12Z; peak inspiratory pressure: $P=0.0007$ V6P versus V6Z; $P=0.0001 \mathrm{~V} 12 \mathrm{P}$ versus $\mathrm{V} 12 \mathrm{Z}$ ). Small levels of auto-PEEP were detected in the V12Z group. End-expiratory pressure could not be reliably measured due to the relatively high respiratory rates in all groups.

TABLE 2. TIDAL VOLUMES AND AIRWAY PRESSURES IN EXPERIMENTAL GROUPS

\begin{tabular}{lcccr}
\hline Groups & $\begin{array}{c}\text { VT } \\
(\mathrm{ml} / \mathrm{kg})\end{array}$ & $\begin{array}{c}\text { PIP } \\
\left(\mathrm{cm} \mathrm{H}_{2} \mathrm{O}\right)\end{array}$ & $\begin{array}{c}\text { Observed PEEP } \\
\left(\mathrm{cm} \mathrm{H}_{2} \mathrm{O}\right)\end{array}$ & $\begin{array}{c}\text { MPaw } \\
\left(\mathrm{cm} \mathrm{H}_{2} \mathrm{O}\right)\end{array}$ \\
\hline Control animals & Spontaneous & $\mathrm{N} / \mathrm{A}$ & $\mathrm{N} / \mathrm{A}$ & $\mathrm{N} / \mathrm{A}$ \\
V6P & 6 & $14.8 \pm 1.3$ & $6.2 \pm 1.0$ & $8.5 \pm 1.0$ \\
V6Z & 6 & $10.0 \pm 0.0$ & $0.0 \pm 0.0$ & $3.6 \pm 0.1$ \\
V12Z & 12 & $18.2 \pm 0.6$ & $1.2 \pm 0.2$ & $6.4 \pm 0.3$ \\
V12P & 12 & $23.2 \pm 0.4$ & $5.3 \pm 0.2$ & $10.2 \pm 0.2$ \\
\hline
\end{tabular}

Definition of abbreviation: MPaw, mean airway pressure; PEEP, positive end-expiratory pressure; PIP, peak inspiratory pressure; $\mathrm{V}_{\mathrm{T}}$, tidal volume. 


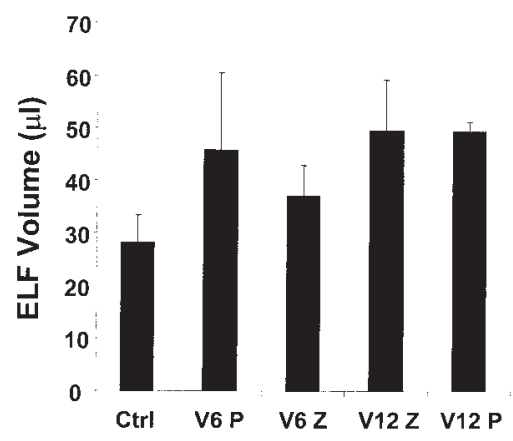

Figure 1. The volume of epithelial lining fluid in ventilated animals remained comparable to that of nonventilated control animals.

\section{Epithelial Lining Fluid and BAL Protein}

Regardless of ventilation protocol, the urea-based volume of epithelial lining fluid remained comparable to that of unventilated control animals (Figure 1). MV without PEEP, regardless of $\mathrm{V}_{\mathrm{T}}$ administered, increased the concentration of BAL protein ( $P=0.038$ V6Z versus Ctrl; $P=0.008$ V12Z versus $C$ trl $)$. The addition of PEEP to either tidal volume protocol normalized BAL protein levels $(P=\mathrm{NS} \mathrm{V12P}$ versus Ctrl; $P=0.05 \mathrm{~V} 12 \mathrm{P}$ versus V12Z; Figure 2).

\section{BAL Nucleotides}

The adenine-based nucleotides were measured in BAL by a highly sensitive fluorescence-based HPLC analysis. Compared with control animals, the total adenine nucleotide concentration was unchanged after small-volume ventilation, regardless of endexpiratory pressure. Total nucleotide levels significantly increased $(95 \%)$ after $2 \mathrm{~h}$ of ventilation with a large $\mathrm{V}_{\mathrm{T}}(P=$ 0.006; Figure 3). The addition of PEEP to the large-volume strategy reduced nucleotides to a level similar to that of control animals. Analysis of individual nucleotide species demonstrated an increase in the levels of ADO and AMP in the V12Z group (ADO: $P<0.0001 \mathrm{~V} 12 \mathrm{Z}$ versus Ctrl; AMP: $P=0.0065 \mathrm{~V} 12 \mathrm{Z}$ versus $C$ trl), which was normalized by the addition of PEEP (ADO: $P=0.004 \mathrm{~V} 12 \mathrm{Z}$ versus V12P; $P=$ NS V12P versus Ctrl; AMP: $P=$ NS V12P versus Ctrl; Figure 4$)$.

The proportion of each nucleotide species expressed as a percentage of total nucleotides is presented in Figure 5. Ventilation with ZEEP, regardless of $\mathrm{VT}$, decreased the relative proportion of ADP $(P=0.022 \mathrm{~V} 6 \mathrm{Z}$ versus $\mathrm{Ctrl} ; P=0.008 \mathrm{~V} 12 \mathrm{Z}$ versus Ctrl); the addition of PEEP to either VT returned ADP levels to control values $(P=\mathrm{NS}$ V6P versus $C t r l ; P=\mathrm{NS}$ V12P versus Ctrl). Similarly, the ATP reduction observed after $6 \mathrm{ml} / \mathrm{kg}$ and $12 \mathrm{ml} / \mathrm{kg}$ volume ventilation $(P=0.049 \mathrm{~V} 12 \mathrm{Z}$ versus $C$ trl $)$ was not detected when PEEP was administered. Compared with unventilated control animals, the relative proportion of $\mathrm{ADO}$

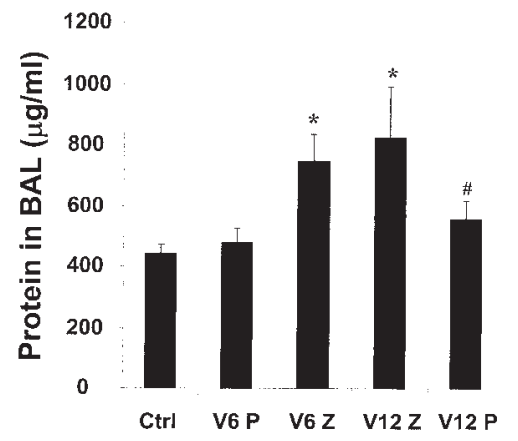

Figure 2. MV with ZEEP (V6Z and V12Z) significantly increased the BAL protein concentration when compared with nonventilated control animals (Ctrl). The addition of $5 \mathrm{~cm} \mathrm{H} 2 \mathrm{O}$ of PEEP (V6P and V12P) normalized the BAL protein concentration. ${ }^{*} P<0.05$ versus $\mathrm{Ctrl} ; \# P<0.05$ versus V12Z.

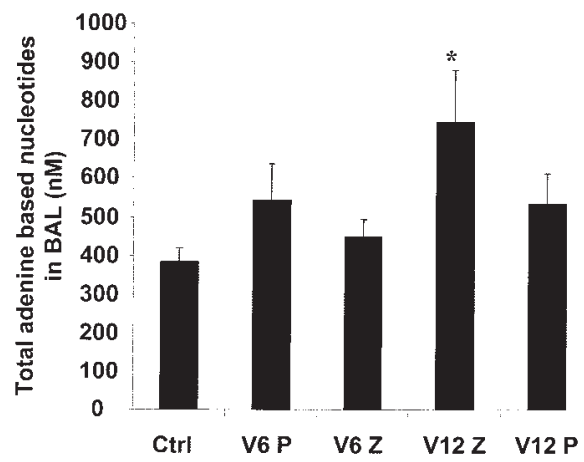

Figure 3. MV with large $V_{t}$ and ZEEP (V12Z) significantly increased the concentration of adenine-based nucleotides in the BAL when compared with nonventilated control animals (Ctrl). Ventilation with small $\mathrm{VT}_{T}(\mathrm{~V} 6 Z$ and $V 6 P)$ or the addition of $5 \mathrm{~cm} \mathrm{H}_{2} \mathrm{O}$ of PEEP (V12P) normalized the $\mathrm{BAL}$ adenyl-nucleotide concentration. ${ }^{*} P<0.05$ versus $\mathrm{Ctrl}$.

was increased in all groups except V6P $(P=0.033$ V6Z versus Ctrl; $P=0.0001 \mathrm{~V} 12 \mathrm{Z}$ versus Ctrl; $P=0.010$ V12P versus Ctrl).

\section{Pulmonary Purine Receptor mRNA Levels}

Purine receptor mRNA was quantified by real-time PCR and expressed as a ratio of GAPDH expression. All tested receptors $\left(\mathrm{P}_{2} \mathrm{Y}_{4}, \mathrm{P}_{2} \mathrm{Y}_{6}, \mathrm{P}_{2} \mathrm{X}_{7}, \mathrm{~A}_{2 \mathrm{~b}}\right.$, and $\left.\mathrm{A}_{3}\right)$ were detected in lung, kidney, and liver tissue. $\mathrm{MV}$, regardless of strategy, did not significantly alter the mRNA levels of $\mathrm{P}_{2} \mathrm{Y}_{4}, \mathrm{P}_{2} \mathrm{Y}_{6}$ or $\mathrm{A}_{3}$ in the lung (Figure 6). Large-volume ventilation without PEEP significantly increased the amount of $\mathrm{A}_{2 \mathrm{~b}}$ mRNA ( $P=0.049 \mathrm{~V} 12 \mathrm{Z}$ versus Ctrl). Adding PEEP normalized the $\mathrm{A}_{2 \mathrm{~b}}$ mRNA level to that of control animals ( $P=\mathrm{NS}, \mathrm{V} 12 \mathrm{P}$ versus Ctrl). MV with the V6P, V12Z, and V12P protocols significantly decreased lung $\mathrm{P}_{2} \mathrm{X}_{7}$ mRNA amounts $(P=$ $0.0288 \mathrm{Ctrl}$ versus V6P; $P=0.0043 \mathrm{Ctrl}$ versus V12Z; $P=0.0005$ Ctrl versus V12P).

\section{Extrapulmonary Purine Receptor mRNA Levels}

In renal tissue, $\mathrm{P}_{2} \mathrm{Y}_{4}, \mathrm{P}_{2} \mathrm{Y}_{6}$, and $\mathrm{A}_{3}$ receptors were constitutively present and expression ratios remained unchanged by $\mathrm{MV}$ (Figure 7A). Renal $A_{2 b}$ mRNA levels were reduced in V6Z,

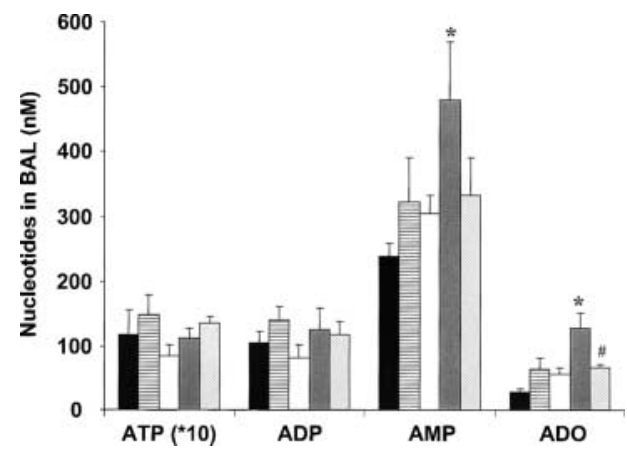

Figure 4. MV with large $V_{t}$ and ZEEP (V12Z) significantly increased the concentrations of AMP and ADO in the BAL when compared with nonventilated control animals (Ctrl). The addition of $5 \mathrm{~cm} \mathrm{H} 2 \mathrm{O}$ of PEEP (V12P) normalized the BAL nucleotide profile. ATP $\left({ }^{*} 10\right)$ : in this graph, the concentrations of ATP have been multiplied by 10 to allow visualization. ${ }^{*} P<0.05$ versus Ctrl. $\# P<0.05$ versus V12Z. Black bars, control animals; horizontal hatched bars, V6P; white bars, V6Z; gray bars, V12Z; diagonally hatched bars, V12P. 


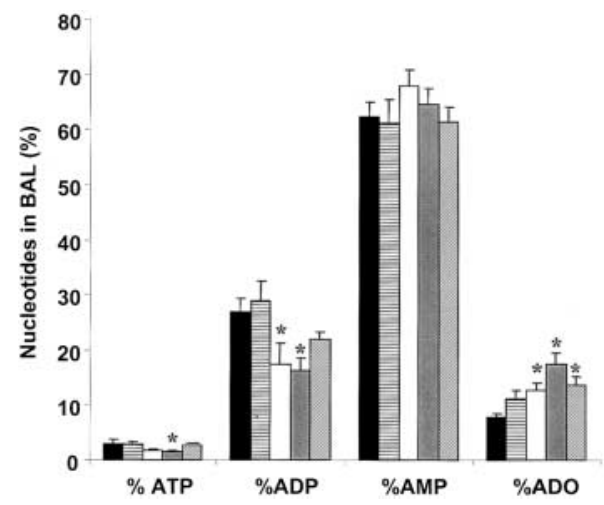

Figure 5. MV altered the relative proportions of adenine based nucleotides ( ${ }^{*} P<0.05$ versus Ctrl). Black bars, control animals; horizontal hatched bars, V6P; white bars, V6Z; gray bars, V12Z; diagonally hatched bars, V12P.

V12Z, and V12P $(P=0.032 \mathrm{~V} 6 \mathrm{Z}$ versus Ctrl; $P=0.059 \mathrm{~V} 12 \mathrm{Z}$ versus Ctrl; $P=0.040 \mathrm{~V} 12 \mathrm{Z}$ versus $\mathrm{Ctrl})$, but were similar to control in V6P $(P=$ NS V6P versus Ctrl $)$. Renal $\mathrm{P}_{2} \mathrm{X}_{7}$ receptor mRNA quantity was not altered by MV. We detected a ZEEPassociated decrease in renal $\mathrm{P}_{2} \mathrm{X}_{7}$ receptor mRNA levels $(P=$ 0.029 both groups with ZEEP versus $C$ trl), which was normalized in animals ventilated with PEEP $(P=$ NS both groups with PEEP versus Ctrl; $P=0.028$ PEEP groups versus ZEEP groups).

In the liver, $\mathrm{P}_{1}\left(\mathrm{~A}_{2 \mathrm{~b}}\right.$ and $\left.\mathrm{A}_{3}\right)$ and $\mathrm{P}_{2} \mathrm{Y}$ expression was unchanged by $\mathrm{MV}$. Large-volume MV without PEEP significantly decreased hepatic $\mathrm{P}_{2} \mathrm{X}_{7}$ receptor mRNA levels $(P=0.023 \mathrm{~V} 12 \mathrm{Z}$ versus Ctrl). The addition of PEEP returned the hepatic $\mathrm{P}_{2} \mathrm{X}_{7}$ levels to control values ( $P=$ NS V12P versus Ctrl; Figure 7B).

\section{Pulmonary Fas and Fas Ligand mRNA Levels}

Pulmonary Fas and Fas ligand (FasL) mRNA levels were quantified by real-time PCR (Figure 8). MV with the V6P, V12Z, and V12P strategies resulted in a significant reduction of FasL mRNA levels $(P=0.003$ V6P versus Ctrl; $P=0.017$ V12Z versus Ctrl; $P=0.022 \mathrm{~V} 12 \mathrm{P}$ versus Ctrl). Similar decreases, although not statistically significant, were observed in the pulmonary mRNA levels of Fas.

\section{DISCUSSION}

Evidence is mounting that MV, particularly with large VTs, may be injurious (1). Data published by the ARDSnet consortium

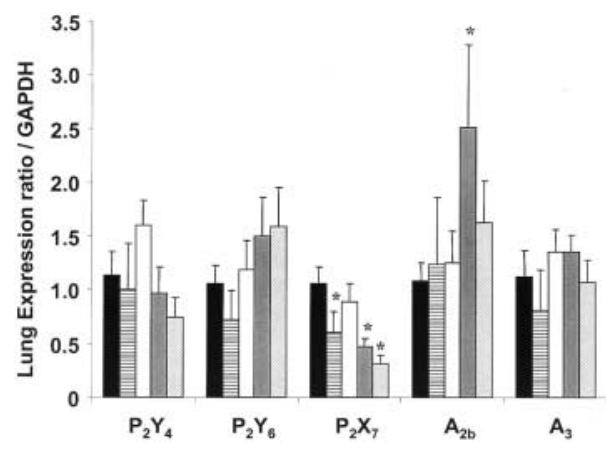

Figure 6. $M V$ altered the pulmonary mRNA levels of $P_{2} X_{7}$ and $A_{2 b}$ purinoceptors, but not that of $\mathrm{P}_{2} \mathrm{Y}_{4}, \mathrm{P}_{2} \mathrm{Y}_{6}$, or $\mathrm{A}_{3}\left({ }^{*} \mathrm{P}<0.05\right.$ versus $\left.\mathrm{Ctrl}\right)$. Black bars, control animals; horizontal hatched bars, V6P; white bars, V6Z; gray bars, V12Z; diagonally hatched bars, V12P. revealed that $\mathrm{V}_{\mathrm{T}}$ limitation during MV yielded a profound reduction in acute respiratory distress syndrome (ARDS)-associated mortality (18). Protective ventilatory strategies have been advocated to reduce ventilator-induced lung injury (VILI) in an effort to improve outcome from pulmonary failure (19).

It has been hypothesized that MV with high end-inspiratory and low end-expiratory pressures is injurious to the lung because both result in the delivery of significant stress forces to pulmonary surfaces (1). It is clear that at very high pressures and large volumes, MV can produce a variety of physical derangements at the alveolar-capillary level. Although shear-associated mechanical failure may account for some of the derangements observed during MV, additional factors likely play a role (e.g., activation of stretch-induced epithelial cation channels [20]). In fact, lung injury and increased capillary permeability can occur even with moderate airway pressures that do not produce overt mechanical stress failures $(20,21)$. These data suggest that there are molecular systems of mechanotransduction that link airway stress to the cellular events causing VILI.

In 1929, Drury and Szent-Gyorgyi demonstrated that nucleotides can independently exert such profound physiologic effects as negative cardiac chronotropy and coronary vasodilatation (22). It has subsequently become clear that nucleotides play an important role as extracellular messengers and orchestrate a broad range of physiologic responses via binding to ubiquitous membrane-bound nucleotide receptors. Purinergic receptors can be broadly divided into two large superfamilies: the ADO-binding $P_{1}$ receptors $\left(A_{1}, A_{2 a}, A_{2 b}\right.$ and $\left.A_{3}\right)$, and the larger $P_{2}$ nucleotide-binding group. The latter can be subdivided into ionotropic $\left(\mathrm{P}_{2} \mathrm{X}\right)$ ligand-gated cation channels and G-protein-coupled $\left(\mathrm{P}_{2} \mathrm{Y}\right)$ purinoceptors, which signal via inositol-triphosphate and $\mathrm{Ca}^{2+}$. Purinoceptors are historically characterized by the rank-order potency of natural and synthetic agonists and antagonists $(3,4)$.

Extracellular nucleotides have been implicated in many cellular processes that may be mechanistically pivotal in VILI. In animal microglial, dendritic and mesangial cells, ATP or its breakdown product, $\mathrm{ADO}$, act via $\mathrm{P}_{2} \mathrm{Y}$ or $\mathrm{A}_{2 \mathrm{a}}$ receptors to mediate proinflammatory effects, such as stimulating interleukin (IL)-6 expression and release $(8,9,23)$. These data suggest that extracellular nucleotides may have complex effects mediated by a variety of metabolic products. In human cell lines, $\mathrm{P}_{2} \mathrm{Y}$-mediated proinflammatory stimulation has been demonstrated in monocytes (IL-8) and astrocytes (IL-1 $\beta)(10,24)$. In contrast, prolonged $\mathrm{P}_{2} \mathrm{X}_{7}$ stimulation leads to apoptosis in a variety of cell cultures $(11,25,26)$.

Large amounts of ATP are released in response to mechanical stimulation by a host of cell types, including nasal epithelial, human bronchial epithelial, endothelial, smooth muscle, and fibroblasts $(5,6)$. It is known that ATP is released in vitro from polarized airway epithelia by luminal mechanical stimulation and stimulates purinoceptors on both the apical and basolateral membranes (27). We have previously demonstrated that MV, with either very large VTs $(40 \mathrm{ml} / \mathrm{kg})$ or pressures $\left(40 \mathrm{~cm} \mathrm{H}_{2} \mathrm{O}\right)$, increases in vivo BAL levels of ATP in a VT/inspiratory pressure-dependent manner $(12,13)$.

In the current study, we examined the effect of comparatively smaller VTs $(6 \mathrm{ml} / \mathrm{kg}$ and $12 \mathrm{ml} / \mathrm{kg})$ on the levels of airway ATP and downstream metabolic products by derivatizing purine nucleotides into ethenopurines and analyzing the product profile by HPLC. We observed that MV, even at $12 \mathrm{ml} / \mathrm{kg}$, produced an increase in total airway adenyl nucleotides and altered the downstream metabolic nucleotide profile. The ventilatory parameters applied were selected based on previous animal data demonstrating that these conditions provide preserved oxygenation over the duration of our experiments (28-30). Although it is known that changes in the concentration of inspired oxygen 

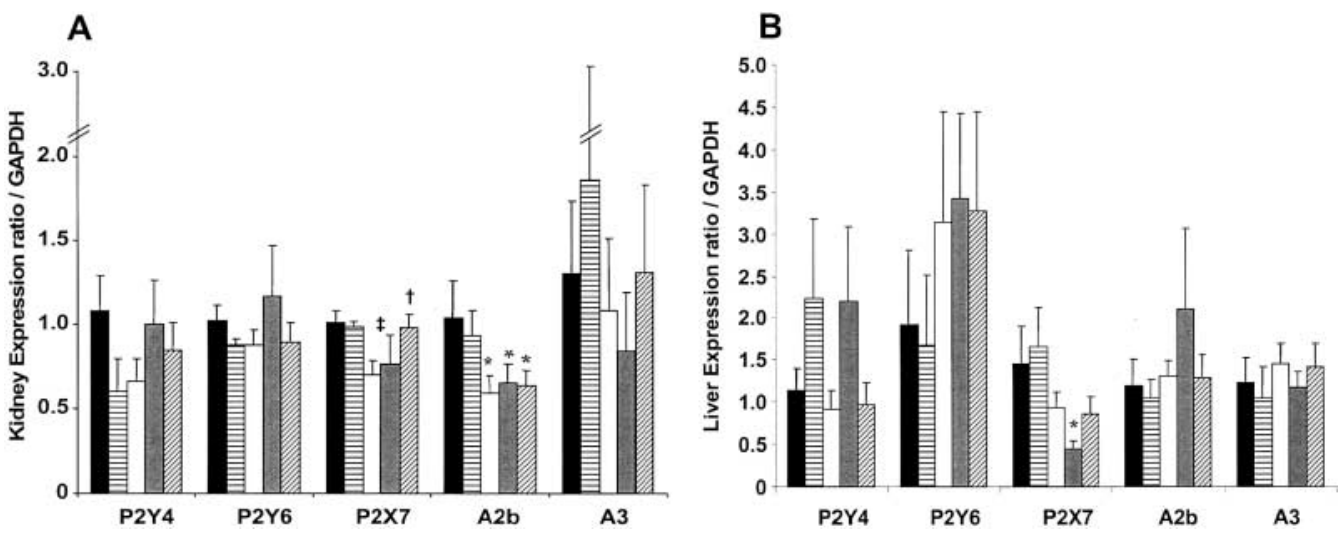

Figure 7. $\mathrm{MV}$ altered the mRNA levels of $\mathrm{P}_{2} \mathrm{X}_{7}$ and $\mathrm{A}_{2 \mathrm{~b}}$ purinoceptors in the kidney $(A)$, and that of $\mathrm{P}_{2} \mathrm{X}_{7}$ in the liver $(B) . P_{2} Y_{4}, P_{2} Y_{6}$, and $A_{3}$ expression remained unchanged in both tissues $\left({ }^{*} P<0.05\right.$ versus Ctrl; $\ddagger P<0.05$ ZEEP versus Ctrl; $\dagger P<0.05$ ZEEP versus PEEP). Black bars, control animals; horizontal hatched bars, V6P; white bars, V6Z; gray bars, V12Z; diagonally hatched bars, V12P.

can impact lung injury, it was not the goal of the current study to evaluate these effects on the purinergic system.

Because a spectrum of purinoceptors are often regionally expressed, and their activities vary depending on relative agonist potency, the local extracellular nucleotide milieu has great impact on cellular responses $(3,4)$. The relative concentrations of extracellular nucleotide species are regulated by numerous enzymes, such as 5'-nucleoside triphosphatase, ecto-nucleotide pyrophasphatase, adenylate kinase, nucleoside diphosphokinase, ecto-apyrase CD39, and ecto-5' -nucleotidase CD73 (7). In our experimental system, ATP and its metabolic products can be measured in nanomolar concentrations by etheno-derivatization and HPLC. The increase in total nucleotides, AMP and ADO observed with large-volume MV, combined with a proportionate decrease in ATP and ADP, can be interpreted at least in part as an enzymatic conversion of the precursors ATP and ADP toward the less phosphorylated metabolites AMP and ADO. Labeling studies, difficult in in vivo systems, will be required to definitively state whether the AMP and ADO rise is due to relatively increased metabolic conversion of ATP/ADP or is a result of release of these nucleotides into the airspaces. Regardless of source, these MV-associated changes could be expected to produce increased purinergic stimulation via the $\mathrm{P}_{1}\left(\mathrm{~A}_{2 \mathrm{~b}}\right)$ pathway (3).

The application of PEEP, generally regarded as a protective strategy during large-volume MV, returned the total adenyl nucleotide levels toward that of unventilated control animals. Similarly, exposure to PEEP normalized the complete etheno-generated metabolic profile so that its appearance was similar to that of control animals. These normalizing effects occurred despite comparatively higher peak and MPaws.

Localization studies have demonstrated that purinergic re- ceptors are expressed in the majority of the cell and tissue types assayed. By real-time reverse transcriptase-PCR, we confirmed that the purinergic receptors $\mathrm{P}_{2} \mathrm{Y}_{4}, \mathrm{P}_{2} \mathrm{Y}_{6}, \mathrm{P}_{2} \mathrm{X}_{7}, \mathrm{~A}_{3}$, and $\mathrm{A}_{2 \mathrm{~b}}$ are constitutively expressed in the unventilated rat lung. Furthermore, our data supports that after only $2 \mathrm{~h}$ of positive-pressure $\mathrm{MV}, \mathrm{P}_{1}$ and $\mathrm{P}_{2} \mathrm{X}$ mRNA concentration patterns can be significantly modified both by applied VT and PEEP.

Exposure to MV resulted in a quantitative decrease in the mRNA of pulmonary $\mathrm{P}_{2} \mathrm{X}_{7}$ in all groups except V6Z, which was the group exposed to the lowest peak and MPaws. This observation suggests that lung $\mathrm{P}_{2} \mathrm{X}_{7}$ mRNA levels are airway pressure-sensitive. It is known that prolonged cell surface $\mathrm{P}_{2} \mathrm{X}_{7}$ stimulation generates a conformational change in receptor transmembrane protein structure, which creates a nonselective transmembrane pore and can initiate pro-apoptotic cellular signals $(11,25,26)$. ATP is a natural agonist for the $\mathrm{P}_{2} \mathrm{X}_{7}$ receptor. Our observation that $\mathrm{MV}$ with $12 \mathrm{ml} / \mathrm{kg}$ VTs resulted in a proportional decrease in airway ATP and a decrease in $\mathrm{P}_{2} \mathrm{X}_{7}$ mRNA levels suggests a ligand-receptor environment conducive to decreased $\mathrm{P}_{2} \mathrm{X}_{7}$ activation. It is intriguing to speculate that apoptotic changes observed by others in association with VILI and ARDS may relate to $\mathrm{P}_{2} \mathrm{X}_{7}$-mediated apoptosis and a consequent decrease in total $\mathrm{P}_{2} \mathrm{X}_{7}$ mRNA in the lung.

We demonstrated that ventilation-associated pulmonary changes in Fas and FasL mRNA levels, measured by real-time PCR, paralleled the changes observed in $\mathrm{P}_{2} \mathrm{X}_{7}$ mRNA levels. It is well established that stimulation of the Fas/FasL system is associated with induction of apoptosis. It is known that Fas and FasL are expressed on pulmonary epithelia and inflammatory cells, and that their expression can be altered in the setting of lung injury (31-34). Although most observations have documented associated changes after prolonged durations (hours to days), it is re-
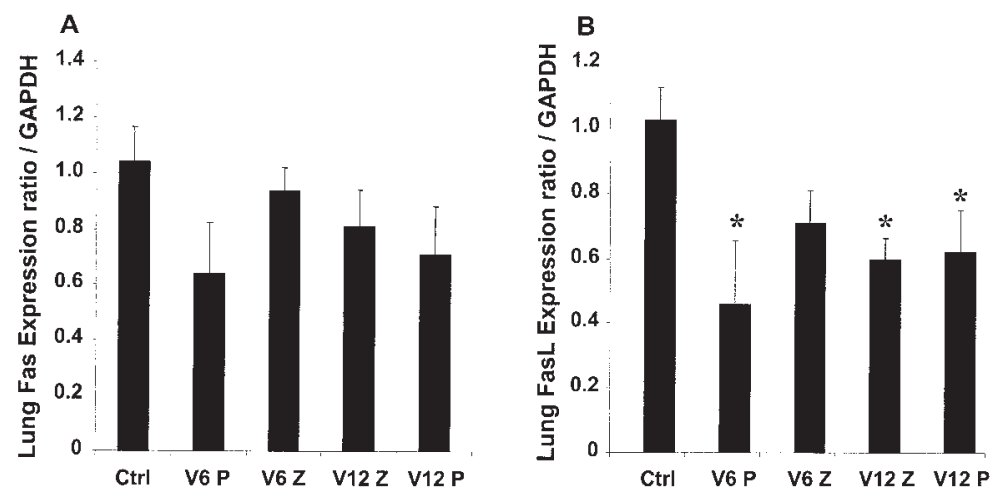

Figure 8. MV altered the pulmonary mRNA levels of Fas $(A)$ and FasL $(B)\left({ }^{\star} P<0.05\right.$ versus $C$ trll). 
markable that we observed decreases in this system over a period of $2 \mathrm{~h}$. It is unclear if these observations result from changes in expression or ventilation-associated changes in the recruitment and residence of pulmonary inflammatory cells. Regardless of the mechanism, it is plausible that either event could have significant implications regarding lung injury.

mRNA levels of the $P_{1}$ purinergic receptor $A_{2 b}$ were similarly responsive to large-volume $\mathrm{MV}$. Whereas ventilation with $6 \mathrm{ml} / \mathrm{kg}$ volumes had no discernable effect on $\mathrm{A}_{2 \mathrm{~b}}$ mRNA quantity, regardless of the applied PEEP, mRNA levels were significantly increased upon $2 \mathrm{~h}$ of exposure to $12 \mathrm{ml} / \mathrm{kg}$ volumes. Comparable to the effect demonstrated on airway extracellular nucleotide levels, the addition of PEEP to the large-volume MV strategy reduced $A_{2 b}$ mRNA to levels not significantly different from unventilated control animals. The large volume MV-associated and PEEP-sensitive increase in both $\mathrm{A}_{2 \mathrm{~b}}$ and its ligand ADO provides a milieu conducive to a comparatively increased stimulation of this receptor.

Others and we have previously shown that MV can be associated with the locoregional release of cytokines $(35,36)$. In bronchial smooth muscle cell cultures, $\mathrm{A}_{2 \mathrm{~b}}$ stimulation has been demonstrated to induce the release of the proinflammatory cytokines IL-6 and monocyte chemoattractant protein-1 (37). Furthermore, ADO stimulation of $\mathrm{P}_{1}$ receptors has been observed to mediate IL-13-induced inflammation and remodeling in the murine lung and regulate IL- 8 production in human mast cell-1 cells $(38,39)$. Given these data, we speculate that the MV-associated increase in $\mathrm{ADO}$ and $\mathrm{A}_{2 \mathrm{~b}}$ receptor mRNA levels may result in activation of the $\mathrm{P}_{1}$ system and could be a mechanistic candidate for the proinflammatory state observed with MV and the syndrome of VILI.

ARDS-related mortality is often associated with the development of multiple system organ dysfunction rather than discrete physiologic failure of the lung (40). Observational studies support the concept that extrapulmonary organ dysfunction may occur in a VT-dependent manner, and that MV can lead to distant organ injury, cytokine elaboration, and even cellular apoptosis (2). We examined the effect of MV, as a sole stimulus, on the tissue mRNA levels of purinergic receptors on organs frequently involved in ARDS-associated multiple system organ dysfunction (i.e., the liver and kidney).

Large-volume MV decreased the mRNA levels of $\mathrm{P}_{2} \mathrm{X}_{7}$ in both the liver and kidney. Both effects were reversed by the application of PEEP. Because these changes appeared after only $2 \mathrm{~h}$ of ventilation, it is possible that the changes in mRNA levels may not represent an actual change of expression, but rather a rapid death or loss of resident cells (either epithelial or inflammatory) or recruitment into the organ of immune/inflammatory cells that do not express $\mathrm{P}_{2} \mathrm{X}_{7}$. Because of VT-dependent increases in intrathoracic pressure and potential pentobarbitalassociated decreases in cardiac output, another explanation is simply an MV-dependent alteration in intraorgan blood volume. However, this hypothesis is not supported by the observation that PEEP reversed the process, despite higher MPaw and Paw values, an effect that could be expected to induce even greater limitations in preload and cardiac output. Unfortunately, the fact that vascular manipulations caused by the placement of indwelling monitoring catheters can impact nucleotide release precluded direct measurement of vascular pressures.

Others have observed that MV induces apoptotic changes in extrapulmonary organs, such as the kidney (2), but the cellular populations responsible for this event were undefined. We describe here MV-associated changes in pulmonary, renal, and hepatic purinoceptor and Fas/FasL mRNA levels, but we did not seek to identify specific apoptotic cell types nor did we determine the physiologic consequences of these alterations.
MV produced a significant decrease in the quantity of renal $\mathrm{A}_{2 b}$ mRNA, an effect not reversed by the application of PEEP. It is known that $A_{2 b}$ receptors are abundantly expressed within the renal preglomerular microcirculation, and their stimulation has been implicated in the regulation of renal blood flow dynamics $(41,42)$. Furthermore, ADO-stimulated $\mathrm{P}_{1}$ agonism has been associated with increased renal erythropoetin (EPO) production, and ADO deficiency with an EPO-depleted state (43). Further studies are required to determine if our observations account for the gross derangements in renal blood flow distribution and EPO-deficient anemia states often associated with MV and the syndrome of VILI.

In summary, our results demonstrate that MV alters the mass and spectrum of extracellular nucleotides in airspaces and modifies purinoceptor mRNA patterns in the lung. These ligand receptor changes could result in the VT-dependent stimulation of distinctive purinergic receptor subtypes, mediating a variety of ventilation-associated cellular responses. Furthermore, we observed that positive-pressure ventilation of the lung, as a sole stimulus, can modify purinoceptor mRNA levels in extrapulmonary tissues, such as the liver and kidney. The application of PEEP as a protective strategy during large-volume ventilation normalized many of the VT-dependent nucleotide and purinoceptor alterations observed with injurious ventilation.

Conflict of Interest Statement: C.D.D. has no declared conflicts of interest; W.R.R has no declared conflicts of interest; B.L.Z. has no declared conflicts of interest; E.R.L. has no declared conflicts of interest; R.C.B. has no declared conflicts of interest; and P.B.R. has no declared conflicts of interest.

Acknowledgments: The authors thank Dr. Wanda O'Neal and Lisa Jones for their support and assistance with real time RT-PCR, and Catharina Van Heusden for her assistance with HPLC analysis.

\section{References}

1. Slutsky AS. Lung injury caused by mechanical ventilation. Chest 1999; 116:9S-15S

2. Imai Y, Parodo J, Kajikawa O, de Perrot M, Fischer S, Edwards V, Cutz E, Liu M, Keshavjee S, Martin TR, et al. Injurious mechanical ventilation and end-organ epithelial cell apoptosis and organ dysfunction in an experimental model of acute respiratory distress syndrome. JAMA 2003;289:2104-2112.

3. Williams M, Jarvis MF. Purinergic and pyrimidinergic receptors as potential drug targets. Biochem Pharmacol 2000;59:1173-1185.

4. Di Virgilio F, Chiozzi P, Ferrari D, Falzoni S, Sanz JM, Morelli A, Torboli M, Bolognesi G, Baricordi OR. Nucleotide receptors: an emerging family of regulatory molecules in blood cells. Blood 2001;97:587-600.

5. Watt WC, Lazarowski ER, Boucher RC. Cystic fibrosis transmembrane regulator-independent release of ATP: its implications for the regulation of P2Y2 receptors in airway epithelia. J Biol Chem 1998;273: 14053-14058.

6. Yegutkin G, Bodin P, Burnstock G. Effect of shear stress on the release of soluble ecto-enzymes ATPase and 5'-nucleotidase along with endogenous ATP from vascular endothelial cells. Br J Pharmacol 2000;129: 921-926.

7. Donaldson SH, Picher M, Boucher RC. Secreted and cell-associated adenylate kinase and nucleoside diphosphokinase contribute to extracellular nucleotide metabolism on human airway surfaces. Am J Respir Cell Mol Biol 2002;26:209-215.

8. Shigemoto-Mogami Y, Koizumi S, Tsuda M, Ohsawa K, Kohsaka S, Inoue K. Mechanisms underlying extracellular ATP-evoked interleukin-6 release in mouse microglial cell line, MG-5. J Neurochem 2001; 78:1339-1349.

9. Scholz-Pedretti K, Pfeilschifter J, Kaszkin M. Potentiation of cytokine induction of group IIA phospholipase A(2) in rat mesangial cells by ATP and adenosine via the A2A adenosine receptor. Br J Pharmacol 2001;132:37-46.

10. Warny M, Aboudola S, Robson SC, Sevigny J, Communi D, Soltoff SP, Kelly CP. P2Y(6) nucleotide receptor mediates monocyte interleukin-8 production in response to UDP or lipopolysaccharide. J Biol Chem 2001;276:26051-26056.

11. Humphreys BD, Rice J, Kertesy SB, Dubyak GR. Stress-activated protein 
kinase/JNK activation and apoptotic induction by the macrophage P2X7 nucleotide receptor. J Biol Chem 2000;275:26792-26798.

12. Rich PB, Douillet CD, Lazarowski ER, Boucher RC. Extracellular nucleotides contribute to ventilator-induced lung injury. Am J Respir Crit Care Med 2003;167:A776.

13. Rich PB, Douillet CD, Mahler SA, Husain SA, Boucher RC. Adenosine triphosphate is released during injurious mechanical ventilation and contributes to lung edema. J Trauma 2003;55:290-297.

14. Tsao TC, Hong J, Li LF, Hsieh MJ, Liao SK, Chang KS. Imbalances between tumor necrosis factor-alpha and its soluble receptor forms, and interleukin-1beta and interleukin-1 receptor antagonist in BAL fluid of cavitary pulmonary tuberculosis. Chest 2000;117:103-109.

15. Lazarowski ER, Tarran R, Grubb BR, Van Heusden CA, Okada S, Boucher RC. Nucleotide release provides a mechanism for airway surface liquid homeostasis. J Biol Chem 2004;279:36855-36864.

16. Huang P, Lazarowski ER, Tarran R, Milgram SL, Boucher RC, Stutts MJ. Compartmentalized autocrine signaling to cystic fibrosis transmembrane conductance regulator at the apical membrane of airway epithelial cells. Proc Natl Acad Sci USA 2001;98:14120-14125.

17. Pfaffl MW. A new mathematical model for relative quantification in realtime RT-PCR. Nucleic Acids Res 2001;29:e45.

18. The Acute Respiratory Distress Syndrome Network. Ventilation with lower tidal volumes as compared with traditional tidal volumes for acute lung injury and the acute respiratory distress syndrome. $N$ Engl J Med 2000;342:1301-1308.

19. Amato MB, Barbas CS, Medeiros DM, Magaldi RB, Schettino GP, Lorenzi-Filho G, Kairalla RA, Deheinzelin D, Munoz C, Oliveira R, et al. Effect of a protective-ventilation strategy on mortality in the acute respiratory distress syndrome. $N$ Engl J Med 1998;338:347-354.

20. Parker JC, Ivey CL, Tucker JA. Gadolinium prevents high airway pressure-induced permeability increases in isolated rat lungs. J Appl Physiol 1998;84:1113-1118.

21. Parker JC, Gillespie MN, Taylor AE, Martin SL. Capillary filtration coefficient, vascular resistance, and compliance in isolated mouse lungs. J Appl Physiol 1999;87:1421-1427.

22. Drury AN, Szent-Gyorgyi A. The physiological activity of adenine compoounds with special reference to their action upon mammalian subtypes. J Physiol 1929;68:213-237.

23. Marriott I, Inscho EW, Bost KL. Extracellular uridine nucleotides initiate cytokine production by murine dendritic cells. Cell Immunol 1999;195: 147-156.

24. John GR, Simpson JE, Woodroofe MN, Lee SC, Brosnan CF. Extracellular nucleotides differentially regulate interleukin-1beta signaling in primary human astrocytes: implications for inflammatory gene expression. J Neurosci 2001;21:4134-4142.

25. Schulze-Lohoff E, Hugo C, Rost S, Arnold S, Gruber A, Brune B, Sterzel RB. Extracellular ATP causes apoptosis and necrosis of cultured mesangial cells via P2Z/P2X7 receptors. Am J Physiol 1998;275:F962-F971.

26. Coutinho-Silva R, Persechini PM, Bisaggio RD, Perfettini JL, Neto AC Kanellopoulos JM, Motta-Ly I, Dautry-Varsat A, Ojcius DM. P2Z/ P2X7 receptor-dependent apoptosis of dendritic cells. Am J Physiol 1999;276:C1139-C1147.

27. Homolya L, Steinberg TH, Boucher RC. Cell to cell communication in response to mechanical stress via bilateral release of ATP and UTP in polarized epithelia. J Cell Biol 2000;150:1349-1360.
28. Torbati D, Camacho MT, Raszynski A, Sussmane JB, Totapally BR, Hultquist K, Wolfsdorf J. Effect of hypothermia on ventilation in anesthetized, spontaneously breathing rats: theoretical implications for mechanical ventilation. Intensive Care Med 2000;26:585-591.

29. Valenza F, Sibilla S, Porro GA, Brambilla A, Tredici S, Nicolini G, Miloso M, Tredici G, Gattinoni L. An improved in vivo rat model for the study of mechanical ventilatory support effects on organs distal to the lung. Crit Care Med 2000;28:3697-3704.

30. Duggan M, McCaul CL, McNamara PJ, Engelberts D, Ackerley C, Kavanagh BP. Atelectasis causes vascular leak and lethal right ventricular failure in uninjured rat lungs. Am J Respir Crit Care Med 2003;167: $1633-1640$

31. Nomoto Y, Kuwano K, Hagimoto N, Kunitake R, Kawasaki M, Hara $\mathrm{N}$. Apoptosis and Fas/Fas ligand mRNA expression in acute immune complex alveolitis in mice. Eur Respir J 1997;10:2351-2359.

32. Hamann KJ, Dorscheid DR, Ko FD, Conforti AE, Sperling AI, Rabe KF, White SR. Expression of Fas (CD95) and FasL (CD95L) in human airway epithelium. Am J Respir Cell Mol Biol 1998;19:537-542.

33. Hashimoto S, Kobayashi A, Kooguchi K, Kitamura Y, Onodera H, Nakajima $\mathrm{H}$. Upregulation of two death pathways of perforin/granzyme and FasL/Fas in septic acute respiratory distress syndrome. Am J Respir Crit Care Med 2000;161:237-243.

34. Kitamura Y, Hashimoto S, Mizuta N, Kobayashi A, Kooguchi K, Fujiwara I, Nakajima H. Fas/FasL-dependent apoptosis of alveolar cells after lipopolysaccharide-induced lung injury in mice. Am J Respir Crit Care Med 2001;163:762-769.

35. Rich PB, Douillet CD, Hurd H, Boucher RC. Effect of ventilatory rate on airway cytokine levels and lung injury. J Surg Res 2003;113:139-145.

36. Tremblay LN, Miatto D, Hamid Q, Govindarajan A, Slutsky AS. Injurious ventilation induces widespread pulmonary epithelial expression of tumor necrosis factor-alpha and interleukin-6 messenger RNA. Crit Care Med 2002;30:1693-1700.

37. Zhong H, Belardinelli L, Maa T, Feoktistov I, Biaggioni I, Zeng D. $\mathrm{A}(2 \mathrm{~B})$ adenosine receptors increase cytokine release by bronchial smooth muscle cells. Am J Respir Cell Mol Biol 2004;30:118-125.

38. Blackburn MR, Lee CG, Young HW, Zhu Z, Chunn JL, Kang MJ, Banerjee SK, Elias JA. Adenosine mediates IL-13-induced inflammation and remodeling in the lung and interacts in an IL-13-adenosine amplification pathway. J Clin Invest 2003;112:332-344.

39. Feoktistov I, Goldstein AE, Biaggioni I. Role of p38 mitogen-activated protein kinase and extracellular signal-regulated protein kinase kinase in adenosine A2B receptor-mediated interleukin-8 production in human mast cells. Mol Pharmacol 1999;55:726-734.

40. Gullo A, Berlot G, Viviani M. The role of adult respiratory distress syndrome in the multiple organ dysfunction syndrome. Acta Anaesthesiol Scand Suppl 1996;109:70-73.

41. Jackson EK, Zhu C, Tofovic SP. Expression of adenosine receptors in the preglomerular microcirculation. Am J Physiol Renal Physiol 2002 283:F41-F51.

42. Martin PL, Potts AA. The endothelium of the rat renal artery plays an obligatory role in A2 adenosine receptor-mediated relaxation induced by $5^{\prime}$-N-ethylcarboxamidoadenosine and N6-cyclopentyladenosine. $J$ Pharmacol Exp Ther 1994;270:893-899.

43. Nagashima K, Karasawa A. Modulation of erythropoietin production by selective adenosine agonists and antagonists in normal and anemic rats. Life Sci 1996;59:761-771. 